\title{
Perancangan Integrated Environmental Performance Measurement System Di Rumah Sakit
}

\author{
Chandra Kurniawan*, Ahmad Mubin, Heri Mujayin Kholik \\ Jurusan Teknik Industri, Fakultas Teknik, Universitas Muhammadiyah Malang \\ Jl. Raya Tlogomas No.246 Malang, Jawa Timur, Phone: +62 341464 318, Fax: +62 341460435 \\ "Surel: ckurniawan842@gmail.com
}

\begin{abstract}
Waste has a negative impact on the environment. Hospital medical waste is a hazardous waste for the environment. Environmental performance measurement systems are used to measure the performance of hospitals in handling waste. The measurement of its environmental performance in the hospital is expected to provide improved sewage treatment systems. AHP (Analytical Hierarchy Process) and OMAX (Objactive Matrix) methods are used to design environmental performance systems at hospitals. The data needed is medical and non medical treatment. Data were collected using pairwise comparison questionnaires. The questionnaire data shows the importance of key environmental performance indicators (KEPI). Results of questionnaires processed using Expert Choice. Expert Choice's output produces weight and consistency ratio. Weighted KEPI results are processed by OMAX method. The OMAX method is used to determine the value of environmental performance. There 41 KEPI aspects of the environment. Based on the results of the environmental performance assessment, liquid waste has the highest weight of 0.229 .
\end{abstract}

Keywords: AHP, Expert Choice, KEPI, OMAX

\begin{abstract}
Abstrak
Limbah memberikan dampak negatif bagi lingkungan. Limbah medis rumah sakit merupakan limbah berbahaya bagi lingkungan. Sistem pengukuran kinerja lingkungan digunakan untuk mengukur kinerja rumah sakit dalam menangani limbah. Pengukuran kinerjanya lingkungan di rumah sakit diharapkan memberikan perbaikan sistem pengolahan limbah. Metode AHP (Analytical Hierarchy Process) dan OMAX (Objective Matrix) digunakan untuk merancang sistem kinerja lingkungan pada rumah sakit. Data yang dibutuhkan adalah pengolahan limbah medis maupun non medis. Data dikumpulkan menggunakan kuisioner perbandingan berpasangan. Data kuesioner menunjukan tingkat kepentingan indikator kunci kinerja lingkungan (KEPI). Hasil kuesioner diolah menggunakan Expert Choice. Output Expert Choice menghasilkan bobot dan consistency ratio. Hasil pembobotan KEPI diolah dengan metode OMAX. Metode OMAX digunakan untuk mengetahui nilai kinerja lingkungan. Terdapat 41 KEPI aspek lingkungan. Berdasarkan hasil penilaian kinerja lingkungan, limbah cair memiliki bobot tertinggi yaitu 0,229.
\end{abstract}

Kata kunci: AHP, Expert Choice, KEPI, OMAX

\section{Pendahuluan}

Sistem pengukuran kinerja berguna untuk menilai efisiensi dan efektivitas aktivitas. Sistem pengukuran kinerja terintegrasi menggunakan keseimbangan antara indikator-indikator kinerja finansial dan non-finansial. Indikator finansial adalah indikator dipicu oleh indikator non finansial. Tanpa kinerja non finansial yang baik akan sangat sukar mendapatkan kinerja finansial yang baik [1]. Sistem manajemen lingkungan merupakan suatu proses yang berjalan dan berinteraksi di mana struktur, tanggung jawab, prosedur, proses dan sumber daya untuk penerapan kebijakan sasaran 
dan targer lingkungan dapat dikoordinasikan dengan usaha-usaha yang sudah ada di bidang lainnya seperti operasional, kesehatan dan keselamatan kerja [2]. Sedangkan pengukuran kinerja lingkungan merupakan bagian penting dari sistem manajemen lingkungan, juga merupakan ukuran hasil dan sumbangan yang dapat diberikan sistem manajemen lingkungan pada perusahaan secara riil dan kongkret. Pengukuran kinerja lingkungan ditafsirkan bermacam cara, antara lain kuantitatif, atau hasil proses, atau juga menyertakan kualitatif dan in process [3].

Rumah Sakit (RS) sebagai sarana perbaikan kesehatan sekaligus sebagai lembaga pendidikan tenaga kesehatan dan penelitian memiliki dampak positif dan negatif terhadap lingkungan. Rumah sakit melaksanakan upaya pelayanan rawat jalan, rawat inap, pelayanan gawat darurat, pelayanan medik, dan non medik menggunakan teknologi. Aktivitas tersebut memengaruhi lingkungan sekitarnya [4]. Instalasi Penyehatan Lingkungan (IPL) Rumah Sakit Umum Daerah (RSUD) Dr. Saiful Anwar menjadi obyek dalam penelitian. RSUD Dr. Saiful Anwar merupakan salah satu RS terbaik di Jawa Timur. RSUD Dr. Saiful Anwar merupakan RS rujukan selain RSUD Dr. Soetomo Surabaya. Dalam kegiatan pengelolaan limbah, IPL RSUD Dr. Saiful Anwar mengolah limbah cair, limbah padat medis Bahan Bahaya Beracun (B3) maupun non medis, dan gas (hasil pembakaran pada mesin insenerator). Pada penelitian ini menggunakan data historis 4 periode untuk mendapatkan rata-rata kinerja lingkungan. Untuk melakukan penilaian kinerja lingkungan dibutuhkan sistem pengukuran kinerja lingkungan yang dapat memenuhi seluruh aspek lingkungan.

Berdasarkan permasalahan, diperlukan perancangan sistem pengukuran kinerja yang mampu mengukur kinerja lingkungan secara efektif dan efisien. Penilaian kinerja harus merepresentasikan seluruh aspek-aspek kinerja Instalasi Penyehatan Lingkungan. Metode yang digunakan dalam sistem pengukuran kinerja adalah IEPMS (Integrated Environmental Performance Measurement System) atau sistem pengukuran kinerja lingkungan. IEPMS fokus pada lingkungan dan menggunakan ukuran-ukuran kuantitatif dan kualitatif $[5,6]$. Pengukuran menghasilkan KEPI (key environmental performance indicator) yang merupakan hasil penjabaran dari visi, misi, dan tujuan dari IPL. KEPI dibobotkan dengan AHP (analytical Hierarchy Process) dan proses scoring menggunakan OMAX (objective matrix). Hasil scoring dari OMAX selanjutnya dievaluasi menggunakan metode TLS (traffic light system). Perancangan sistem kinerja lingkungan diharapkan meningkatkan kinerja dari IPL.

\section{Metodologi}

Langkah awal tahap perancangan sistem kinerja lingkungan adalah menentukan ukuran lingkungan. Ukuran lingkungan selanjutnya diturunkan menjadi aspek-aspek lingkungan. Aspek-aspek inilah yang menjadi dasar dalam penentuan KEPI. Langkah berikutnya adalah pengumpulan data primer dan sekunder. Data primer diperoleh dari wawancara dengan pihak-pihak yang berkepentingan mengenai proses pengelolaan limbah dan melakukan penyebaran kuesioner. Sedangkan untuk data sekunder membutuhkan data historis capaian kinerja rumah sakit dalam pengelolaan lingkungan tahun 2013-2016.

Penentuan KEPI didasarkan pada aspek-aspek lingkungan. KEPI diverifikasi oleh pihak perusahaan. Tujuan verifikasi adalah mengecek hasil rancangan KEPI sesuai kriteria penilaian kinerja lingkungan yang diharapkan oleh pihak perusahaan. Tahap selanjutnya adalah melakukan pembobotan pada tiap ukuran, aspek, dan KEPI tersebut dengan menggunakan metode pembobotan AHP. AHP merupakan suatu model pendukung keputusan yang dikembangkan oleh Thomas L. Saaty. Model pendukung 
keputusan ini akan menguraikan masalah multi faktor atau multi kriteria yang kompleks menjadi suatu hierarki, hierarki didefinisikan sebagai suatu representasi dari sebuah permasalahan yang kompleks dalam suatu struktur multi level dimana level pertama adalah tujuan, yang diikuti level faktor, kriteria, subkriteria, dan seterusnya ke bawah hingga level terakhir dari alternatif [7]. Dalam proses pembobotan AHP menggunakan perbandingan berpasangan dengan skala atau tingkat kepentingan 1 sampai 9. Pembobotan berdasarkan hasil kuesioner. Hasil kuesioner selanjutnya diolah menggunakan software Expert Choice..

Tahapan selanjutnya adalah tahap skoring. Pada tahap ini, hasil pembobotan AHP di pakai untuk metode OMAX (objective matrix). Metode OMAX adalah suatu metode sistem skor yang memperhatikan metrik-metrik pengukuran dari KPI/KEPI yang ada dengan melakukan konsolidasi metrik tersebut menjadi ukuran tunggal yang sering disebut dengan current performance. Model ini berhasil ditemukan oleh James L. Riggs di Oregon State University [8]. Metode OMAX menggabungkan kriteria-kriteria produktivitas ke dalam suatu bentuk yang terpadu dan berhubungan satu sama lain. Susunan model OMAX berupa matriks terdiri dari:

\section{Kriteria}

Merupakan indikator kinerja kunci (dalam hal ini KEPI) yang akan diukur kinerjanya, dan dinyatakan dengan sesuai dengan metrik yang digunakannya.

\section{Performance}

Merupakan tempat diletakkan hasil dari perhitungan terhadap KPI/KEPI. Hasil yang diperoleh selanjutnya dicantumkan pada baris performance untuk indikator kunci yang diukur.

\section{Butir-butir Matriks}

Terdapat dalam badan matriks yang disusun oleh besaran-besaran pencapaian mulai dari tingkat 1 (hasil yang terjelek) sampai dengan tingkat 10 (hasil terbaik). Sedangkan pada tingkat 3 merupakan data pengukuran untuk data pada periode sebelumnya.

\section{Score/skor}

Hasil dari pengukuran dari data aktual yang dibandingkan dengan tingkat kinerja yang paling mendekati. Score menunjukkan kinerja KPI/KEPI yang diukur sesuai dengan metrik standar yang digunakan yaitu 1 sampai 10 .

5. Weight/bobot

Menyatakan bobot dari indikator-indikator kunci yang hendak diukur. Nilai bobot ini diperoleh dari hasil pengolahan AHP pada tahapan sebelumnya.

\section{Value/nilai}

Menyatakan hasil perkalian dari skor kinerja untuk KPI/KEPI yang ada dengan bobot Indikator kuncinya.

\section{Performance Indicator}

Menyatakan jumlah nilai dari semua KPI/KEPI yang telah diukur. Pada bagian ini akan dilakukan perbandingan kinerja periode sebelumnya dengan periode pengukuran yang dinyatakan dengan indeks. Bila indeks menunjukkan nilai lebih besar dari 1 berarti kinerja periode pengukuran lebih baik kinerjanya dibanding dengan kinerja periode sebelumnya. Bila nilai indeks kurang dari 1, maka menunjukkan sebaliknya, yaitu kinerja awal lebih baik dari kinerja di periode pengukuran.

\section{Score Performance}

Dalam metode OMAX, perhitungan dilakukan dengan menggunakan score, score disini bernilai dari 0 sampai 10 di mana:

- Score 0 menyatakan kondisi terjelek yang terjadi 
- Score 3 menyatakan hasil-hasil yang ingin dicapai dalam kondisi normal selama proses pengukuran berlangsung

- Score 10 menyatakan perkiraan realistis target yang mungkin akan tercapai oleh perusahaan dalam suatu kurun waktu tertentu

- Score 2 dilakukan interpolasi antara 0 dan 3

- Score 4,5,6,7,8,9, sama seperti skor 2 hanya saja disini interpolasi dilakukan antara 3 sampai 10

Tahap akhir perancangan sistem kinerja lingkungan adalah tahap evaluasi. Pada tahap evaluasi dilakukan dengan menggunakan metode TLS (Traffic Light System). Metode TLS mengategorikan KEPI-KEPI pada perancangan sistem ke dalam kategori warna. Warna merah (buruk) merupakan KEPI yang menghasilkan skor antara 0 sampai 2, warna kuning (baik) merupakan KEPI yang menghasilkan skor antara 3 sampai 7, dan warna hijau (sangat baik) merupakan KEPI yang menghasilkan skor antara 8 sampai 10 .

\section{Hasil dan Pembahasan}

Penelitian ini menggunakan data historis tahun 2013 hingga 2016. Data diambil pada beberapa aspek Instalasi Penyehatan Lingkungan. Aspek yang dijadikan data penelitian dapat dilihat pada Tabel 1.

Tabel 1 Data Aspek Objek Penelitian

\begin{tabular}{cc}
\hline Ukuran Lingkungan & Aspek Lingkungan \\
\hline Limbah & Limbah cair \\
& Limbah Padat \\
Kualitas Lingkungan Eksternal & GasEmisi \\
& Udara Ambien \\
Program K3 & Kandungan tanah \\
& Program APD \\
Manajemen Lingkungan & Pelatihan K3 \\
& Program Audit Linngkungan \\
\hline
\end{tabular}

\subsection{Perancangan Sistem Kinerja}

Pada Tahap awal perancangan sistem kinerja menghasilkan ukuran dan aspek lingkungan (lihat Tabel 1). Ukuran dan aspek lingkungan dipecah menjadi KEPI untuk proses pembobotan, skoring, dan evaluasi kinerja. Hasil rancangan KEPI dapat dilihat pada Tabel 2.

\subsection{Pembobotan Ukuran dan Aspek Lingkungan}

Pembobotan ukuran menggunakan Expert Choice. Hasil pembobotan dari Expert Choice dapat dilihat pada Gambar 1. Hasil pembobotan aspek dan KEPI dapat dilihat pada Tabel 3. 
Tabel 2 Rancangan KEPI (key to environmental performance indicator)

\begin{tabular}{|c|c|c|c|c|}
\hline No. & $\begin{array}{c}\text { Ukuran } \\
\text { Lingkungan }\end{array}$ & $\begin{array}{c}\text { Aspek } \\
\text { Lingkungan }\end{array}$ & KEPI & $\begin{array}{c}\text { No. } \\
\text { KEPI }\end{array}$ \\
\hline \multirow[t]{21}{*}{1.} & Limbah & Limbah Cair & Suhu Air Limbah & 1. \\
\hline & & & Nilai $\mathrm{pH}$ & 2. \\
\hline & & & Kadar BOD & 3. \\
\hline & & & Kadar COD & 4. \\
\hline & & & Jumlah TSS & 5 . \\
\hline & & & Kadar Ammonia & 6. \\
\hline & & & Kadar Phosphat & 7. \\
\hline & & & Kadar Coli Tinja & 8. \\
\hline & & Limbah Padat & Kadar Mercury (Hg) & 9. \\
\hline & & $(\mathrm{Abu}$ & Kadar Plumbumb (Pb) & 10. \\
\hline & & Insinerator) & Kadar Cadmium (Cd) & 11. \\
\hline & & & Kadar Chrom (Cr) & 12. \\
\hline & & & Kadar Copper & 13. \\
\hline & & Gas Emisi & Jumlah Dust/debu & 14. \\
\hline & & & Kadar Hidrogen Flourida (Hf) & 15. \\
\hline & & & Kadar Hidrogen Klorida (HCl) & 16. \\
\hline & & & Kadar Nitrogen Dioksida $\left(\mathrm{NO}_{2}\right)$ & 17. \\
\hline & & & Kadar Sulfur Dioksida $\left(\mathrm{SO}_{2}\right)$ & 18. \\
\hline & & & Kadar Hidrokarbon (HC) & 19. \\
\hline & & & Kadar Karbon Monoksida (CO) & 20. \\
\hline & & & Tingkat Opacity & 21. \\
\hline \multirow[t]{15}{*}{2.} & Kualitas & Udara Ambien & Kadar Nitrogen Dioksida $\left(\mathrm{NO}_{2}\right)$ & 22. \\
\hline & Lingkungan & & Kadar Sulfur Dioksida $\left(\mathrm{SO}_{2}\right)$ & 23. \\
\hline & Eksternal & & Kadar Ammonia & 24. \\
\hline & & & Kadar Hidrogen Sulfida $\left(\mathrm{H}_{2} \mathrm{~S}\right)$ & 25. \\
\hline & & & Jumlah Dust/debu & 26. \\
\hline & & & KadarHidrokarbon (HC) & 27. \\
\hline & & & Kadar Oxidant $\left(\mathrm{O}_{3}\right)$ & 28. \\
\hline & & & Kadar $\mathrm{Pb}$ & 29. \\
\hline & & & Kebisingan & 30. \\
\hline & & Kandungan & Kadar Mercury (Hg) & 31. \\
\hline & & Tanah IPL & Kadar Plumbumb (Pb) & 32. \\
\hline & & & Kadar Cadmium (Cd) & 33. \\
\hline & & & Kadar Chrom (Cr) & 34. \\
\hline & & & Kadar Copper & 35. \\
\hline & & & Kadar Zinc (Zn) & 36. \\
\hline \multirow[t]{3}{*}{3.} & Program K3 & Penggunaan & Jumlah APD yang tersedia per tahun & 37. \\
\hline & & APD & Jumlah kecelakaan kerja per tahun & 38. \\
\hline & & Pelatihan K3 & Jumlah program pelatihan K3 & 39. \\
\hline \multirow[t]{4}{*}{4.} & Manajemen & Program & Jumlah audit lingkungan tiap tahun & 40. \\
\hline & Lingkungan & Audit & & \\
\hline & & Lingkungan & & \\
\hline & & $\begin{array}{l}\text { Penghargaan } \\
\text { Lingkungan }\end{array}$ & $\begin{array}{l}\text { Jumlah penghargaan lingkungan per } \\
\text { tahun }\end{array}$ & 41. \\
\hline
\end{tabular}




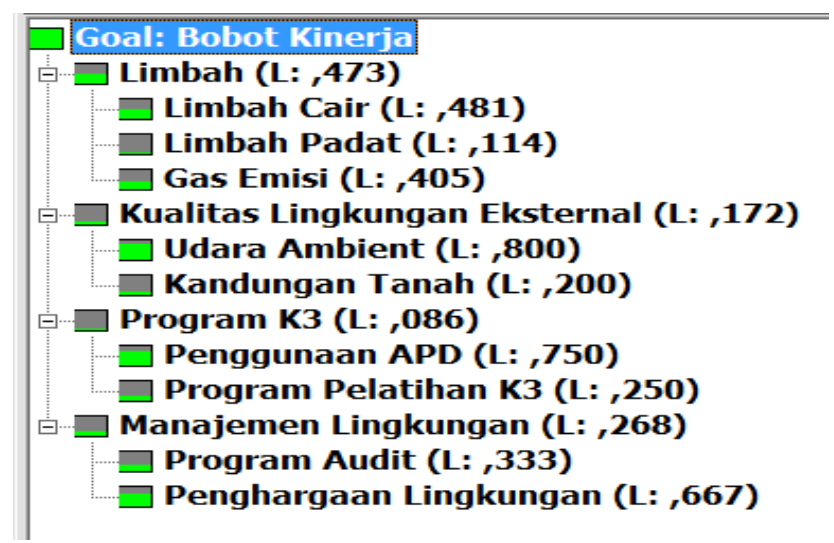

Gambar 1 Hasil Pembobotan Expert Choice

Tabel 3 Hasil pembobotan Aspek dan KEPI (setelah normalisasi)

\begin{tabular}{cccccc}
\hline No. KEPI & Bobot & No. KEPI & Bobot & No. KEPI & Bobot \\
\hline $\mathbf{1 .}$ & 0,006 & 15. & 0,047 & 29. & 0,031 \\
$\mathbf{2 .}$ & 0,01 & 16. & 0,029 & 30. & 0,011 \\
$\mathbf{3 .}$ & 0,017 & 17. & 0,014 & 31. & 0,014 \\
$\mathbf{4 .}$ & 0,02 & 18. & 0,015 & 32. & 0,004 \\
$\mathbf{5 .}$ & 0,031 & 19. & 0,03 & 33. & 0,008 \\
$\mathbf{6 .}$ & 0,035 & 20. & 0,017 & 34. & 0,005 \\
$\mathbf{7 .}$ & 0,034 & 21. & 0,016 & 35. & 0,002 \\
$\mathbf{8 .}$ & 0,076 & 22. & 0,021 & 36. & 0,001 \\
$\mathbf{9 .}$ & 0,026 & 23. & 0,006 & 37. & 0,016 \\
$\mathbf{1 0 .}$ & 0,009 & 24. & 0,004 & 38. & 0,049 \\
$\mathbf{1 1 .}$ & 0,007 & 25. & 0,027 & 39. & 0,021 \\
$\mathbf{1 2 .}$ & 0,006 & 26. & 0,008 & 40. & 0,089 \\
$\mathbf{1 3 .}$ & 0,005 & 27. & 0,014 & 41. & 0,179 \\
$\mathbf{1 4 .}$ & 0,023 & 28. & 0,016 & & \\
\hline
\end{tabular}

\subsection{Skoring Sistem Kinerja Lingkungan}

Setelah hasil pembobotan didapatkan, selanjutnya dilakukan proses skoring pada tiap KEPI untuk mengetahui skor dari tiap-tiap KEPI. Hasil OMAX Aspek Limbah cair dapat dilihat pada Tabel 4. Hasil OMAX Aspek Limbah Padat dapat dilihat pada Tabel 5.

Tabel 4 Hasil OMAX Pada Aspek Limbah cair

\begin{tabular}{ccccccccc}
\hline Limbah Cair & KEPI 1 & KEPI 2 & KEPI 3 & KEPI 4 & KEPI 5 & KEPI 6 & KEPI 7 & KEPI 8 \\
\hline Performance & 28,8 & 7,8 & 3,61 & 18,33 & 15,4 & 0,054 & 0,47 & 168,7 \\
Skor & 0 & 10 & 10 & 10 & 10 & 8 & 10 & 10 \\
Bobot & 0,006 & 0,01 & 0,017 & 0,02 & 0,031 & 0,035 & 0,034 & 0,076 \\
Nilai & 0 & 0,1 & 0,17 & 0,2 & 0,31 & 0,28 & 0,34 & 0,76 \\
Total Nilai & & & & & & & & 2,16 \\
\hline
\end{tabular}


Tabel 5 Hasil OMAX Pada Aspek Limbah Padat

\begin{tabular}{cccccc}
\hline Limbah Padat & KEPI 9 & KEPI 10 & KEPI 11 & KEPI 12 & KEPI 13 \\
\hline Performance & 0,0005 & 0,0016 & 6 & 0,051 & 0,0001 \\
Skor & 0 & 10 & 0 & 1 & 9 \\
Bobot & 0,026 & 0,009 & 0,007 & 0,006 & 0,005 \\
Nilai & 0 & 0,09 & 0 & 0,006 & 0,045 \\
Total Nilai & & & & & 0,141 \\
\hline
\end{tabular}

Hasil OMAX Aspek Gas Emisi dapat dilihat pada Tabel 6. Hasil OMAX Aspek Udara Ambien dapat dilihat pada Tabel 7. Hasil OMAX Aspek Kandungan Tanah dapat dilihat pada Tabel 8. Hasil OMAX Aspek Penggunaan APD dan Pelatihan K3 dapat dilihat pada Tabel 9. Dan Hasil OMAX Aspek Program Audit dan Penghargaan dapat dilihat pada Tabel 10.

Tabel 6 Hasil OMAX Pada Aspek Gas Emisi

\begin{tabular}{ccccccccc}
\hline Emisi Gas & KEPI 14 & KEPI 15 & KEPI 16 & KEPI 17 & KEPI 18 & KEPI 19 & KEPI 20 & KEPI 21 \\
\hline Performance & 21,81 & 1 & 1,77 & 92,18 & 5,18 & 11,58 & 3,78 & 5,7 \\
Skor & 4 & 0 & 5 & 4 & 10 & 10 & 10 & 0 \\
Bobot & 0,023 & 0,047 & 0,029 & 0,014 & 0,015 & 0,03 & 0,017 & 0,016 \\
Nilai & 0,092 & 0 & 0,145 & 0,056 & 0,15 & 0,3 & 0,17 & 0 \\
Total Nilai & & & & & & & & 0,913 \\
\hline
\end{tabular}

Tabel 7 Hasil OMAX Pada Aspek Udara Ambien

\begin{tabular}{|c|c|c|c|c|c|c|c|c|c|}
\hline \multirow{2}{*}{$\begin{array}{c}\text { Udara } \\
\text { Ambient }\end{array}$} & $\begin{array}{c}\text { KEPI } \\
22 \\
\end{array}$ & $\begin{array}{c}\text { KEPI } \\
23 \\
\end{array}$ & $\begin{array}{c}\text { KEPI } \\
24 \\
\end{array}$ & $\begin{array}{c}\text { KEPI } \\
25 \\
\end{array}$ & $\begin{array}{c}\text { KEPI } \\
26 \\
\end{array}$ & $\begin{array}{c}\text { KEPI } \\
27 \\
\end{array}$ & $\begin{array}{c}\text { KEPI } \\
28 \\
\end{array}$ & $\begin{array}{c}\text { KEPI2 } \\
9 \\
\end{array}$ & $\begin{array}{c}\text { KEPI } \\
30 \\
\end{array}$ \\
\hline & 27,14 & 47,9 & 18,32 & 5,23 & 12,95 & 6,38 & 50,41 & 0,04 & 48,5 \\
\hline Skor & 7 & 10 & 5 & 2 & 10 & 9 & 10 & 10 & 10 \\
\hline Bobot & 0,021 & 0,006 & 0,004 & 0,027 & 0,008 & 0,014 & 0,016 & 0,031 & 0,011 \\
\hline Nilai & 0 & 0,06 & 0,02 & 0,054 & 0,08 & 0,126 & 0,16 & 0,31 & 0,11 \\
\hline Total Nilai & & & & & & & & & 0,92 \\
\hline
\end{tabular}

Tabel 8 Hasil OMAX Pada Aspek Kandungan Tanah

\begin{tabular}{ccccccc}
\hline Kandungan & KEPI 31 & KEPI 32 & KEPI 33 & KEPI 34 & KEPI 35 & KEPI 36 \\
\cline { 2 - 7 } Tanah & 0,0014 & 0,0095 & 0,0104 & 0,0195 & 0,0136 & 1,4743 \\
Skor & 6 & 9 & 6 & 10 & 8 & 5 \\
Bobot & 0,014 & 0,004 & 0,008 & 0,005 & 0,002 & 0,001 \\
Nilai & 0,084 & 0,036 & 0,048 & 0,05 & 0,016 & 0,005 \\
Total Nilai & & & & & & 0,239 \\
\hline
\end{tabular}


Tabel 9 Hasil OMAX Pada Aspek Penggunaan APD dan Pelatihan K3

\begin{tabular}{cccc} 
Performance & KEPI 37 & KEPI 38 & KEPI 39 \\
\cline { 2 - 4 } Skor & 38 & 0 & 4 \\
Bobot & 7 & 10 & 10 \\
Nilai & 0,016 & 0,049 & 0,021 \\
Nilai Total & 0,112 & 0,49 & 0,21 \\
\hline
\end{tabular}

Tabel 10 Hasil OMAX Pada Aspek Program Audit dan Penghargaan

\begin{tabular}{ccc} 
Performance & KEPI 40 & KEPI 41 \\
\cline { 2 - 3 } & 12 & 1 \\
Skor & 10 & 10 \\
Bobot & 0,089 & 0,179 \\
Nilai /Total & 0,712 & 1,79 \\
\hline
\end{tabular}

\subsection{Evaluasi Sistem Pengukuran Kinerja Lingkungan}

Evaluasi sistem pengukuran kinerja dilakukan dengan menggunakan TLS dengan memasukkan KEPI ke dalam kategori warna. Hasil evaluasi TLS dapat dilihat pada Gambar 2.

\section{Simpulan}

Identifikasi aspek-aspek lingkungan pada kinerja lingkungan Instalasi Penyehatan Lingkungan (IPL) mengacu pada ukuran lingkungan. Ukuran-ukuran tersebut antara lain limbah, kualitas lingkungan eksternal, program K3, dan manajemen lingkungan. Keempat ukuran lingkungan tersebut selanjutnya diturunkan lagi menjadi 9 aspek lingkungan, yaitu limbah cair, limbah padat, gas emisi, udara ambient, kandungan tanah IPL, penggunaan APD (Alat Pelindung Diri), program pelatihan K3, program audit, dan penghargaan lingkungan. Perancangan sistem pengukuran kinerja lingkungan menghasilkan 41 KEPI (key environmental performance indicator) yang diperoleh dari aspek-aspek lingkungan hasil identifikasi pada awal penelitian. Pada aspek Limbah cair menghasilkan 8 KEPI, aspek Limbah Padat menghasilkan 5 KEPI, aspek Gas Emisi menghasilkan 8 KEPI, aspek Udara Ambient menghasilkan 9 KEPI, aspek Kandungan Tanah menghasilkan 6 KEPI, aspek Penggunaan APD menghasilkan 2 KEPI, dan aspek Program K3, Program Audit, Penghargaan Lingkungan masing-masing menghasilkan 1 KEPI. Dalam melakukan perancangan sistem pengukuran kinerja juga melakukan pembobotan untuk mengetahui ukuran atau aspek yang dinilai paling penting dalam menentukan tingkat performa dari suatu unit kerja. Ukuran yang memiliki bobot tertinggi adalah Limbah, dengan nilai bobot sebesar 0,473 ini berarti perusahaan lebih fokus pada limbah, sedangkan untuk aspek limbah cair merupakan aspek dengan nilai bobot tertinggi sebesar 0,229 ini artinya limbah cair merupakan aspek yang sangat diperhatikan oleh perusahaan. Pada hasil TLS (traffic lights system) dihasilkan 25 KEPI kategori hijau 
(sangat baik), 10 KEPI kategori kuning (baik), dan 6 KEPI kategori merah (kurang baik). Namun untuk KEPI dengan kategori merah tersebut hanya KEPI nomor 1 yang memang perlu diperbaiki kinerjanya, ini disebabkan KEPI tersebut sudah mendekati ambang batas baku mutu yang ditetapkan, sedangkan untuk kelima KEPI kategori merah lainnya masih sangat jauh dari ambang batas baku mutunya namun memiliki performa yang kurang memuaskan dibanding tahun-tahun sebelumnya. Untuk hasil total penilaian kinerja lingkungan adalah 7,687.

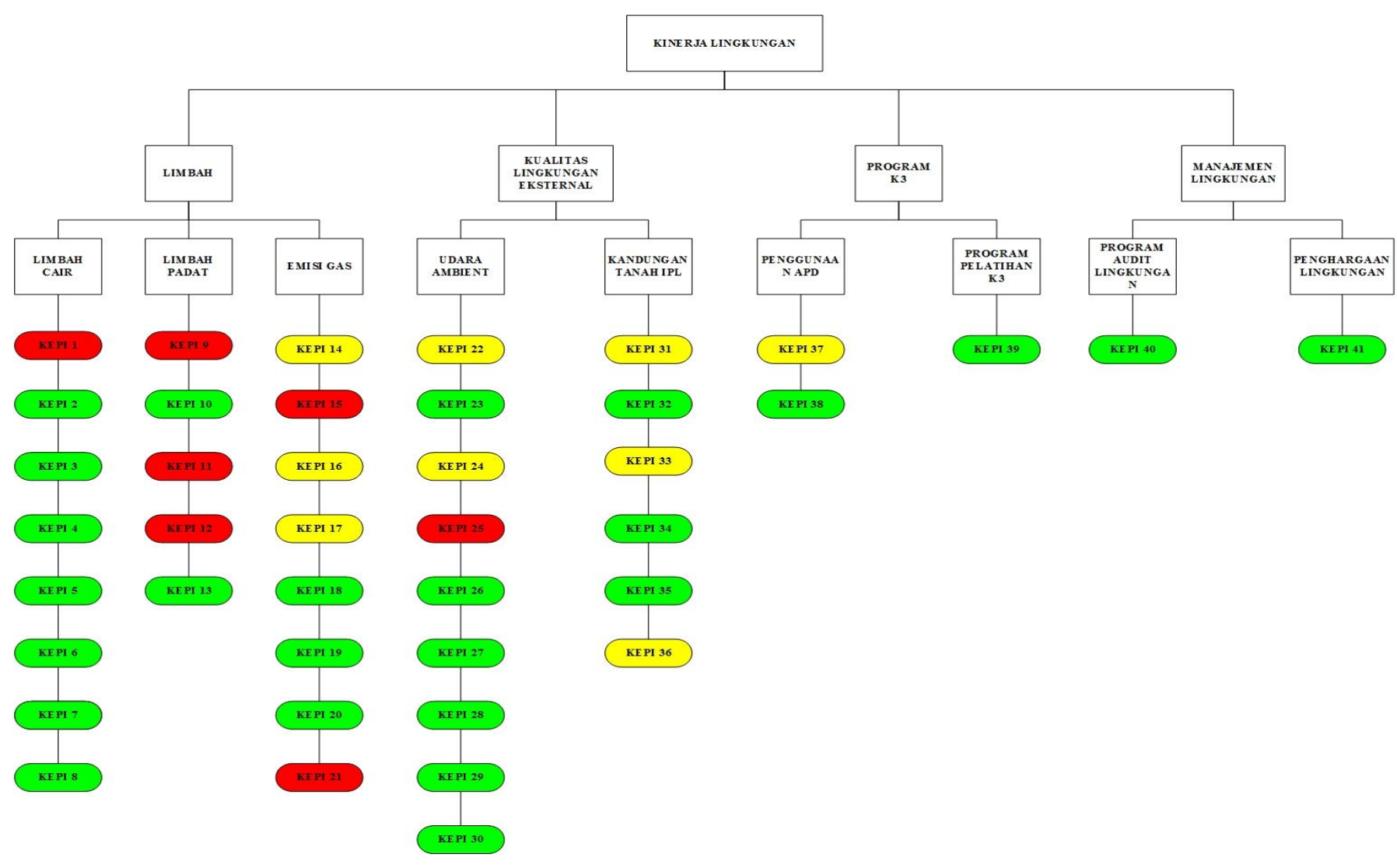

Gambar 2 Hasil TLS Sistem Pengukuran Kinerja Lingkungan

\section{Referensi}

[1] I. Vanany, Performance Measurement Model Dan Aplikasi. Surabaya: ITS Press, 2009.

[2] P. Sunu and R. M. S. Putra, Melindungi Lingkungan dengan Menerapkan ISO 14001: Gramedia WIdiasarana Indonesia (Grasindo), 2001.

[3] L. Lasdi, "Balanced Scorecard Sebagai Rerangka Pengukuran Kinerja Perusahaan Secara Komprehensif dalam Lingkungan Bisnis Global," Jurnal Widya Manajemen dan Akuntansi, vol. 2, pp. 150-169, 2002.

[4] A. Wiku, "Sistem Manajemen Lingkungan Rumah Sakit," ed. Jakarta: PT. RajaGrafindo Persada, 2009.

[5] F. R. Abidin, "Perancangan Sistem Pengukuran Kinerja Lingkungan Dengan Menggunakan Pendekatan Integrated Environmental Performance Measurement System (Iepms)-Analytical Network Process (ANP)(Studi Kasus di PG. Kebon Agung Malang-JawaTimur)," University of Muhammadiyah Malang, 2015. 
[6] D. Tyteca, "On the measurement of the environmental performance of firms-a literature review and a productive efficiency perspective," Journal of environmental management, vol. 46, pp. 281-308, 1996.

[7] T. Saaty, "Proses Hirarki Analitik untuk Pengambilan Keputusan dalam Situasi yang Kompleks (Terjemahan)," ed: PT Pustaka Binaman Pressindo, Jakarta, 1991.

[8] E. Günther and A. Sturm, "Environmental performance measurement," in Environmental Management Accounting: Informational and Institutional Developments, ed: Springer, 2002, pp. 223-229. 